\title{
ETHICS AND SOCIAL RESPONSIBILITY IN ARCHIVAL INSTITUTIONS: ELEMENTS TO CONSIDER
}

\author{
Ética y responsabilidad social en archivos: \\ elementos a considerar
}

\section{Vicent Giménez-Chornet}

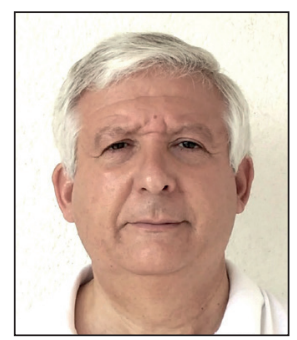

Vicent Giménez-Chornet, doctor in History, is professor at the Polytechnic University of Valencia and a member of the Committee 50 on Documentation at the Spanish Association of Standardization (Aenor). He has been archivist, and president of the Professional College of Library and Information Science of Valencia (Cobdcv), Spain.

https://orcid.org/0000-0003-1183-9058

DCADHA, Documentation Universitat Politècnica de València Camí de Vera, s/n. 46022 Valencia, Spain vigicho@har.upv.es

\begin{abstract}
This article proposes ethical and social responsibilities for archival institutions to supplement the ethical codes for records management that focus on individual ethical behavior. The methodology is based on case studies, from the author's long career as professional archivist in administrative and historical archives. The original contributions of this study are ethical and social responsibility proposals from the perspective of archival institutions, not the staff, which could help these institutions extend their ethical code and formulate new strategies to benefit the community.
\end{abstract}

\section{Keywords}

Social responsibility; Ethical codes; Archival institutions; Ethics in archives.

\section{Resumen}

Consideraciones sobre la ética y sobre la responsabilidad social de las entidades archivísticas, con el objetivo de que completen los códigos éticos de la actividad en la gestión documental que se centra en el comportamiento ético de las personas. La metodología se basa en el conocimiento de casos del autor, por su larga trayectoria como profesional archivero, tanto de archivos administrativos como de históricos. La originalidad del estudio reside en la propuesta de elementos éticos y de responsabilidad social desde el punto de vista de la entidad y no del comportamiento del personal, que podrá ayudar a estas entidades a ampliar su código ético y a formular nuevas estrategias para beneficiar a la comunidad.

\section{Palabras clave}

Responsabilidad social; Códigos éticos; Instituciones de archivo; Ética en archivos.

Giménez-Chornet, Vicent (2017). "Ethics and social responsibility in archival institutions: Elements to consider". El profesional de la información, v. 26, n. 4, pp. 765-770.

https://doi.org/10.3145/epi.2017.jul.20

\section{Introduction ${ }^{1}$}

In Spain, archival institutions are responsible for managing and conserving records produced by people and legal entities in the course of their activity. Such institutions may depend directly on the producing body (if the company or public authority body has an archive with staff and services) or they may be established by law and receive documentation by transfer (they may be other public archives within a national archive system, or they may be private entities with a contract to protect records, safeguarding the confidential nature of what they receive). From the perspective of the institution, rather than its archivists, ethical and social responsibilities have their own particular features that are determined by the importance and exclusivity of the records in its custody. This aspect has not been considered from the perspective of archival institutions, which have not drafted their own ethical codes. 
Collections of records are exclusive because the producing entity (the body or individual who engages in an activity) creates them without generating copies (which is not the case with library records) and the loss of the records would leave a gap in the documentary heritage. Collections are important - for businesses they serve as evidence of activities, as proof of rights, or simply bear testimony so that the business can continue with its activity efficiently (for example, keeping clinical records whose loss would cause serious detriment to patients). Collections are also important for society in terms of accountability (Roper, 2003) and in short, ensure transparent management and activity in institutions (Berggren; Bernshteyn, 2007), and good governance in democracies (Dikopoulou; Mihiotis, 2003).

\section{Archival institutions have not drafted their own ethical codes}

Ethics for archival staff are regulated through the codes of various professional collectives and associations. This approach helps to establish archivists' neutrality and impartiality, while their profession is in the midst of disputes over policies on memory (Gilliland, 2011). These professional ethical codes emphasize staff conduct and values;

- how to promote access, understand historical records, preserve primary sources;

- commitment to protecting records;

- social responsibility towards employers;

- defense of cultural heritage;

- professional judgment in appraising, acquiring, and processing collections of records to select and maintain;

- etc.

The Society of American Archivists (SAA, 2012) and the International Council on Archives (ICA, 1996) are two organizations with codes of ethics.

There are indications, from a business perspective, that codes of conduct are insufficient and need to be supplemented with ethical initiatives. Therefore, a model for collaboration based on individual ethical behavior, supported by senior management, is needed (Svensson; Wood, 2008). The social role and responsibility of business is no longer limited to supplying goods and services, it now extends to social behaviors and values, and impacts public life (Agatiello, 2008).

Archivists' ethical codes do not resolve or influence areas that lie outside the competence of professional archivists and are, therefore, not their responsibility. Archivists must perform their duties responsibly to protect the integrity of the records in their care, but they are not responsible for financing or making the necessary budget allocations for this task. Archivists should follow good practices when appraising and selecting records, but they are not responsible for introducing a record appraisal and selection policy (budgeting for record appraisal committee expenses, appointing professionals to these committees, establishing meeting calendars, prioritizing appraisal needs from the perspective of the company's business activities, etc.). Archivists must promote access to records, but they are not responsible for establishing the restrictions legally available to a state or for the restrictions decided by a company's business policy. Archivists are responsible for achieving professional excellence by updating their knowledge, but they are not responsible for their company's or institution's decision to allocate funds towards updating knowledge in their employees (all employees, not just archivists) to achieve more effective information management and knowledge generation. In this context, archival institutions and record-producing entities need to address essential issues of ethical and social responsibility to supplement professional ethical codes in order to ensure a global commitment to ethics. Obviously archival institutions are governed by real people, and these people must apply an ethical code of archivists. It is important to note that in some cases those responsible for archival institutions are not archivists, or may not have exclusive archival responsibilities. In this article we refer to persons who have responsibilities for archival technical duties and the duties of governing or managing institutions that guard the records. Spanning activities include records management in a broader responsibility than that of the archival technician job, being responsible for issues such as personnel management, enterprise policy, economic management, dissemination, etc.

Codes of conduct are insufficient and need to be supplemented with ethical initiatives

\section{Contexts where ethical breaches may occur}

Next is a closer examination of settings where ethical problems might arise, including a description of cases where ethics within an organization may be vulnerable. We consider the situation from the organization's point of view, rather than from the archives perspective; in archives, ethical codes are known and have been published by, for example, the aforementioned Society of American Archivists or the International Council on Archives. In the following cases, archivists are subject to practices and guidelines that organizations and managers introduce in order to defend their business policy, corporate image, or business line, without considering whether they are in breach of ethical considerations or social responsibility towards the community. Abela (2008) has indicated that business ethics is challenging also because business are controversial. Other studies have examined the role ethical codes of conduct play in the representation of archivists and their work. These studies examined codes of ethics for concepts of professionalism, and considered the relationships between archivists, records creators, records users, employers, and the general public (Dingwall, 2004; Turner, 2011).

Next, we will review the research related to the people who are responsible for the management of archival institutions' cases. 
Case 1. Lack of freedom of expression and communication. When archivists, or other workers in an organization, are not allowed to express their opinions about how or what documents are managed. Technical meetings are not held to resolve any management problems that the organization may have and/or archivists receive orders from their superiors that prevent management of specific documents -in particular documents that may be newsworthy or of legal interest for the community. For example, a town council may prevent the archivist from diffusing the minutes of plenary meetings, or a public television program may not allow transparent financial management because they do not want to reveal pressure from economic or political groups.

Case 2. The organization promotes non-ethical behaviors. Public or private organizations may coerce archivists to alter the integrity of a file, telling them to add or remove documents to change the general purpose of the file, or to provide partial information so that the truth of a matter cannot be established. Generalized absence of control over the sheets in a file (by not applying the General international standard archival description [ISAD (G)] or Encoded archival description (EAD) in a database to record the volume of the document unit) means that, out of political interest, senior management in a firm or other pressure groups can coerce archivists to modify the integrity of files. Changes may be made by archivists themselves (which would be an offence) or with the aid of a representative from the pressure group.

Case 3. Deliberate neglect of document maintenance. In major organizations which have been active for many years (public authorities may keep documents dating from the $19^{\text {th }}$ century or earlier, and firms may have been active for several decades), managers may decide they wish to destroy documents as a way of freeing up physical space in their buildings. As they consider the documents no longer have any legal interest or primary value, they do not set up an evaluation committee to decide whether the documents should be destroyed for lack of any primary or secondary value (interest for history and culture), but comply with their country's legal requirements for document destruction. Some practices used to destroy these documents under the guise of legality may be related to storage on premises where it is known that water will get in when it rains heavily. When the documents are wet, the necessary steps are taken to destroy them. In other cases, cleaning staff or other maintenance employees, with no technical knowledge of the work, may be ordered to clean premises containing documents and, unaware of the seriousness and complexity of the undertaking, they may inadvertently destroy archive documents, considering them to be "just old papers".

Case 4. Sale of data. The organization neglects to control information, making it easy for senior management or document management staff to sell data. A council may provide telecommunications companies with the records of new entries on the electoral role for their business line. Senior management in a historical archive will not allow the organization to have a policy of transparent document management if they use their knowledge of the documents to sell data and information to people seeking genealogical or other types of information. They may prevent the production of inventories and catalogs or hide those that already exist in order to sell the information they have privileged access to.

Case 5. Precarious work. Various strategies are used to avoid hiring archives' staff under contractual arrangements or categories that are not in keeping with an archivist's level of knowledge and professional qualifications, such as administrative contracts in firms, or contractual levels below graduate level in public authorities. Also, firms sometimes make employees work longer probationary periods on very low pay, or use volunteers for qualified technical work.

Case 6. Unfair competition. Entities that diffuse archival documentation, through reuse or open data policies, may obtain information from other document-producing entities without clearly stating that fact in order to gain unfair competitive advantage over other producer entities. They may use this information system for web promotion, positioning, or to sell data.

\section{Archival institutions and record-produ-} cing entities need to address essential issues of ethical and social responsibility to supplement professional ethical codes in order to ensure a global commitment to ethics

Case 7. Apathy over the quality of technical work. Senior management does not have updated technical expertise, either because they are older staff who have not made, or find it hard to make, the effort to keep up-to-date with information and communication technologies, or because their personal interests and aptitudes do not lead them to update their knowledge. In order to conceal their lack of professionalism, these senior managers prevent their staff from progressing, or from proposing or updating technical archiving work, by limiting or cancelling new document management proposals, especially in view of the challenges of electronic management of documents produced by organizations. In this context, senior management may also limit investment in updating staff expertise, despite the company's solvency, to avoid furthering expertise among possible competitors for senior management posts. They also neglect to introduce a quality system to avoid evaluation of their technical management and prevent people from identifying management deficiencies.

Case 8. Obstacles to staff promotion. The organization has no procedure for promoting staff to higher positions of responsibility after ongoing training or professional development. Public authorities often promote internally, but have no staff promotion system. Thus they avoid higher remuneration and prevent entry into senior management of people who are able to make observations and suggest technical approaches that would eliminate senior management's monopoly over information and the way the work is done.

Case 9. Preventing introduction of a transparent system. A transparent management system is optional in some cases, (especially in private companies) and in others obligatory 
(especially in public authorities). Archives and transparency are closely linked, because accessing documents is a way of finding out about an organization's actions and enables it to demonstrate its credibility to the public. However, some private organizations may engage in practices that limit or prevent transparency, such as not organizing their archives, not describing document units which makes them difficult to locate, or not having staff responsible for answering external requests for information. Public authorities may not apply current legislation and act like private firms, avoiding liability for breaching documentary accessibility regulations by not having staff specifically responsible for archive services.

Case 10. Difficulties reconciling work and personal life. Currently, most employment regulations in Western countries provide both sexes with equal employment opportunities, but these can only become a reality when both sexes enjoy the same domestic, family, and personal arrangements during working hours and outside them. Organizations may avoid adopting reconciliation arrangements for its employees by assigning greater workloads that make employees feel obligated to continue with inflexible working hours or by not allowing employees leave in order to resolve family matters.

\section{Ethics in archival institutions}

The ethical elements we propose are not the direct or exclusive competence of archivists, but must be promoted and adopted by the company's senior executives. We propose the following points for consideration:

Point 1. Archival institutions should promote freedom of expression and ideas in all records management practices.

Point 2. Archival institutions should not infringe on the dignity and integrity of individuals. They should protect employees integrity when using personal information, preserving their independence against any interference or self-interest that may affect independent professional judgment or impartiality; managers should not request, promote, or order unethical conduct.

Point 3. Archival institutions should use the appropriate information as required by legal regulations.

Point 4. Archival institutions should ensure the integrity and authenticity of the information in the documentation they create and manage, applying policies that establish opportune measures to protect the documentary heritage.

Point 5. Archival institutions should guarantee the application of data protection legislation by designing security measures appropriate to the level of sensitivity of personal data, especially in digital environments.

Point 6. Archival institutions should remunerate the work of professionals appropriately, avoiding contractual formats that are not in keeping with the professional qualifications required for the post.

Point 7. Archival institutions should prevent employees from receiving external benefits for the use of information from the records they manage or that are in the custody of the organization.
Point 8. Archival institutions should avoid conduct or behavior that involves unfair competition. The organization should establish its mission and its policies on information management and information reuse and should announce them clearly to the rest of society.

Point 9. Archival institutions should promote quality in technical records management work, allocating resources for the acquisition of software or hardware and investing in policies to apply national or international standards for archival description and management.

Point 10. Archival institutions should promote the application of quality process management systems and encourage staff participation by incorporating various human resources in decision making and allocating economic and/or material resources.

Point 11. Archival institutions should promote the introduction of an innovative system to improve productivity and quality in records management.

Point 12. Archival institutions should promote employee training and research to improve records management efficiency.

The concept and practice of corporate social responsibility has been evolving since the late $19^{\text {th }}$ and early $20^{\text {th }}$ centuries

Point 13. Archival institutions should promote the introduction of citizen information systems that guarantee transparency in the institution's services and business lines.

Point 14. Archival institutions should promote the reconciliation of work and their employees' personal and family lives.

Point 15. Archival institutions should work to eliminate barriers to accessibility and technical processes of records management in order to recruit and employ persons with disabilities.

Point 16. Archival institutions should engage in lawful relationships with other authorities, companies, and citizens, and should not accept or offer presents or commissions that may condition decisions or constitute bribes, especially by providing transparent access to documentary information or by diffusing said information for use or reuse by society.

Point 17. Archival institutions should introduce appropriate measures to guarantee real physical and virtual access to information in the records they manage, within the legal limits.

Point 18. Archival institutions should guarantee fair treatment for everyone, employees, users, and customers, regardless of gender, race, religion, etc.

Point 19. Archival institutions should ensure respect for all employees taking into account their considerations and in terms of appreciating and valuing their rights, qualities, skills, and knowledge. 
Point 20. Archival institutions should apply a quality system to ensure their services are appropriate to their functions and competencies.

\section{Archival institutions' social responsibility}

The concept and practice of corporate social responsibility has been evolving since the late $19^{\text {th }}$ and early $20^{\text {th }}$ centuries when business owners like Andrew Carnegie, Henry Ford, and George Cadbury began to apply health programs for their employees or create housing provisions for workers as an exercise of social responsibility in their business environment. Social responsibility in business continues today; the World Business Council for Sustainable Development proposal, states:

"Corporate social responsibility is the continuing commitment by business to contribute to economic development while improving the quality of life of the workforce and their families as well as of the community and society at large" (Bassen; Jastram; Meyer, 2005).

Currently, social responsibility can be contemplated from a variety of viewpoints, such as the economic responsibility to generate profit, the legal responsibility to comply with legal regulations, the ethical responsibility to comply with social expectations not contemplated by law, or as a discretionary, voluntary responsibility to engage in additional behaviors or activities desired by the community, such as philanthropic, cultural, or social initiatives (Galbreath, 2009). We only take into account archival institutions' social responsibility, not the responsibility of a records producer in their line of business. We therefore disregard proposals linked to profit or compliance with the law (which is assumed) and the abovementioned ethical aspects in order to focus on proposals concerning discretionary social responsibility, about what an archival institution can do to benefit its community. In general, archival institutions should adopt corporate social responsibility to promote actions designed to encourage a positive impact on the environment, users, employees, society, stakeholders, and the economy. In short, businesses can give back to society through corporate social responsibility.

Archival institutions should adopt corporate social responsibility to promote actions designed to encourage a positive impact. In short, businesses can give back to society through corporate social responsibility

\section{Social responsibility actions}

Point 1. Protecting the environment by promoting the rational use of energies, the efficient choice of infrastructures and the use of less aggressive materials (fire prevention gases, chemicals for restoring records, etc.).

Point 2. Providing theoretical and practical training in archival knowledge.
Point 3. Strengthening culture in society through cultural activities like exhibitions, publications, visits, etc.

Point 4. Reusing information, permitting the use of documentary information that can generate benefits for society.

Point 5. The right to know, diffusing records that society has the right to know about to improve decision making in politics, economics, or other aspects of personal life.

Point 6. Capturing and protecting business archives in the community to save its documentary heritage.

Point 7. Diffusing records online, through the appropriate databases and search engines, to facilitate access for society.

Point 8. Research, conducting and diffusing research and analysis to satisfy the needs for knowledge detected in society to achieve its objectives as community.

Point 9. Establishing a system for dealing with complaints and claims over breach of the institution's obligations or the community's rights.

The ethical aspects of records management are not limited to archivists' professional approach; instead, there is a broad spectrum of points related to the institution for which senior management, rather than technical archival sta$\mathrm{ff}$, is responsible

\section{Conclusion}

The ethical aspects of records management are not limited to archivists' professional approach; instead, there is a broad spectrum of points related to the institution for which senior management, rather than technical archival staff, is responsible. The ethical points the institution must assume supplement the ethics of records management.

Top level management of archival institutions and document-producing agencies has a duty to ensure the ethical responsibility of the actions carried out in its corporation. The abandonment of this responsibility can cause practices to be carried out to the detriment of the user community (lack of access to documents due to professional shortcomings of the employees -who perhaps have not been selected with the appropriate professional profile, for different reasons- abandonment in implementing new technologies for document management, avoidance of quality systems, etc.) and to the detriment of the organization itself (negligence in implementing policies of innovation, denigrating treatment and low remuneration to its workers, reversing in the practice of charging illegally for providing information services, absence of recycling programs, etc.) that can cause a bad public image.

The practices of the cases listed are not usually made public. It is not done by the top management nor employees, for different reasons linked to their benefit, and because they are 
not pressured by citizens or public opinion, who are often unaware of these behaviors. In public administrations the archive inspection figure could solve many of these behaviors, but unfortunately has fallen into disuse, perhaps mistakenly associated with policing. The inspection is a useful tool to detect deficiencies and anomalies and, above all, to propose solutions that should be verifiable in another future inspection.

Archival institutions can also exercise social responsibility to benefit the community where they work. Various actions linked to the records management of archives can give back to the community while also generating knowledge and encouraging transparency to promote a democratic society.

In public administrations the archive inspection figure could solve many misbehaviors, but unfortunately it has fallen into disuse, perhaps mistakenly associated with policing

\section{Note}

1. Although this article is based on actual cases in Spain and Latin America, they can not be specifically cited because they are not found in judicial decisions.

\section{Bibliography}

Abela, Andrew V. (2008). "Digesting the raisins of wrath: Business, ethics, and the archival profession". The American archivist, v. 71, pp. 203-209.

https://doi.org/10.17723/aarc.71.1.g674617g204g7142

Agatiello, Osvaldo R. (2008). "Ethical governance: beyond good practices and standards". Management decision, v. 46, n. 8, pp. 1132-1145.

https://goo.gl/xcuoCm

https://doi.org/10.1108/00251740810901345

Bassen, Alexander; Jastram, Sarah; Meyer, Katrin (2005). “Corporate social responsibility. Eine begriffserläuterung". Zeitschrift für wirtschafts und unternehmensethik, v. 6, n. 2, pp. 231-236. http://www.ssoar.info/ssoar/handle/document/35887

Berggren, Erik; Bernshteyn, Rob (2007). “Organizational transparency drives company performance". Journal of management development, v. 26, n. 5, pp. 411-417.

https://goo.gl/FQpRTc

https://doi.org/10.1108/02621710710748248

Dikopoulou, Anastasia; Mihiotis, Athanassios (2012). "The contribution of records management to good governance". The TQM journal, v. 24, n. 2, pp. 123-141.

https://goo.gl/568ers

https://doi.org/10.1108/17542731211215071

Dingwall, Glenn (2004). "Trusting archivists: The role of archival ethics codes in establishing public faith". The American archivist, v. 67, n. 1, pp. 11-30.

https://goo.gl/n69NeA

Galbreath, Jeremy (2009). "Building corporate social responsibility into strategy". European business review, v. 21, n. 2, pp. 109-127.

https://espace.curtin.edu.au/handle/20.500.11937/35406 https://doi.org/10.1108/09555340910940123

Gilliland, Anne (2011). "Neutrality, social justice and the obligations of archival education and educators in the twenty-first century". Archival science, v. 11, n. 3-4, pp. 193-209. https://goo.gl/zN7s5d

https://doi.org/10.1007/s10502-011-9147-0

ICA (1996). ICA code of ethics.

http://www.ica.org/en/ica-code-ethics

Roper, Michael (2003). "Archives and the public good: Accountability and records in modern society". Journal of documentation, v. 59, n. 5, pp. 617-619 https://doi.org/10.1108/00220410310499645

SAA (2012). SAA core values statement and code of ethics. Society of American Archivists.

http://www2.archivists.org/statements/saa-core-valuesstatement-and-code-of-ethics\#core_values

Svensson, Göran; Wood, Greg (2008). "International standards of business conduct: Framework and illustration". European business review, v. 20, n. 3, pp. 260-274.

https://doi.org/10.1108/09555340810871446

Turner, Margaret (2011). "The ethical archivist". Records management journal, v. 21, n. 3, pp. 237-239.

https://doi.org/10.1108/09565691111186902

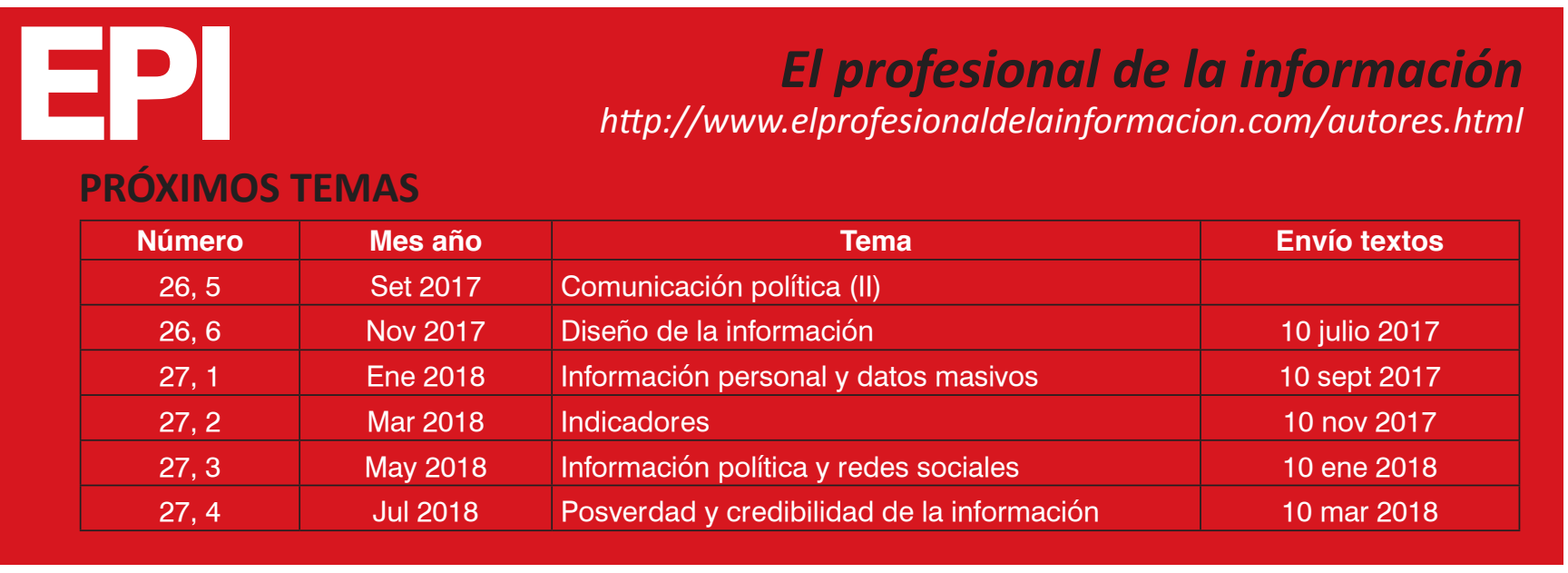

